\title{
Transparent exopolymer particle (TEP) dynamics in the eastern Mediterranean Sea
}

\author{
E. Bar-Zeev ${ }^{1}$, T. Berman ${ }^{2}$, E. Rahav $^{1}$, G. Dishon ${ }^{1}$, B. Herut ${ }^{3}$, \\ N. Kress ${ }^{3}$, I. Berman-Frank ${ }^{1, *}$

\begin{abstract}
${ }^{1}$ Mina and Everard Goodman Faculty of Life Sciences, Bar-Ilan University, Ramat Gan, Israel
${ }^{2}$ Israel Oceanographic and Limnological Research, The Yigal Allon Kinneret Limnological Laboratory, Midgal, Israel
\end{abstract} \\ ${ }^{3}$ Israel Oceanographic and Limnological Research, National Institute of Oceanography, Haifa, Israel
}

\begin{abstract}
Depth and spatial distribution patterns of transparent exopolymer particles (TEP) were measured during 2 east to west cruise transects across the ultra-oligotrophic Levantine basin, eastern Mediterranean Sea (SESAME, September 2008; ISRLEV, July 2009), and at 2 stations 20 and $50 \mathrm{~km}$ offshore (2008). TEP distribution was examined relative to chlorophyll a concentrations, bacterial production, and alkaline phosphatase activity (APA), taken as a measure of phosphorus (P) stress. During the stratified period, TEP levels were highest in a $5 \mathrm{~m}$ surface layer and correlated positively with APA as P concentrations decreased. On the transects, TEP concentrations from both surface and depth $(1000 \mathrm{~m})$ samples increased from west to east, corresponding to a pattern of increasing oligotrophy. In pelagic waters, maximal rates of bacterial production and TEP concentrations were consistently measured in surface samples. These contained abundant large (170 $\mu \mathrm{m}) \mathrm{TEP}$ with numerous associated bacteria, possibly derived from algal or bacterial release or detritus. Lowest TEP concentrations were found in the deep chlorophyll maximum layer where TEP appeared as small $(\sim 4 \mu \mathrm{m})$ particles with only few attached bacteria. In deeper (300 to $1000 \mathrm{~m}$ ) samples, both TEP concentrations and size increased, with most particles having associated bacteria. Our data augment previous studies on the formation of TEP and the subsequent utilization of this material by heterotrophic bacteria both in the euphotic zone and in deeper waters. Moreover, our study suggests that in ultra-oligotrophic environments such as the Levantine basin, TEP plays an especially important role in carbon cycling and transportation.
\end{abstract}

KEY WORDS: TEP · Mediterranean Sea $\cdot$ Levantine basin $\cdot$ Bacterial production · Carbon cycling

Resale or republication not permitted without written consent of the publisher

\section{INTRODUCTION}

Transparent exopolymer particles (TEP) are microscopic $(\sim 1$ to $>200 \mu \mathrm{m})$, organic particles consisting mainly of acidic polysaccharides and detected by staining with Alcian Blue (Passow \& Alldredge 1955); they are ubiquitous in both marine and freshwater environments (Passow 2002). In the open ocean, TEP are derived via 2 pathways: (1) abiotically, by coagulation of colloidal precursors in the pool of dissolved organic matter (DOM) (Passow 2000, Verdugo \& Santschi 2010) and of cellular debris from planktonic organisms, or (2) biotically, resulting directly from algal or bacterial ex- tracellular excretion or mucilage, or from microbial breakdown of larger marine snow particles. TEP formation from dissolved precursors may be stimulated by turbulence or by bubble adsorption (Zhou \& Mopper 1998, Passow 2002). Senescent or nutrient-stressed algae and cyanobacteria have been shown to generate TEP (Grossart et al. 1997, Engel 2004, Berman-Frank et al. 2007). Therefore, relatively greater amounts of TEP may be expected in late phases of algal blooms (Passow 2002) or with increasing oligotrophy of water masses (Engel 2004).

The gel-like structure, high surface area, and extremely sticky character of TEP support coagulation 
processes (Verdugo \& Santschi 2010) and enhance the formation and sedimentation of larger aggregates such as marine snow (Passow 2002, Engel et al. 2004, Patara et al. 2009). In some marine environments, between 50 and $90 \%$ of the total bacterial marine community may be associated with these particles and form 'hot spots' of intense microbial activity and nutrient cycling that are significant in the recycling of particulate organic carbon (POC) to dissolved organic carbon (DOC) (Passow 2002, Verdugo et al. 2004, Azam \& Malfatti 2007). Sedimentation of TEP-associated 'hot spots' from the surface may be important in the transport of particulate organic material and microorganisms to deeper waters (Smith \& Azam 1992, Azam \& Malfatti 2007, Bar-Zeev et al.2009, Verdugo \& Santschi 2010). During sedimentation, TEP can also function as a direct source of carbon and other nutrients for higher trophic level organisms such as protists, micro-zooplankton, and even nekton (Passow 2002, Engel et al. 2004).

The organic carbon pool in the ocean contains both POC and DOC. TEP microgels may act as a 'bridge' between DOC and larger particulates, thereby forming an important intermediary pool of organic matter (Beauvais et al. 2003, Engel et al. 2004, Verdugo et al. 2004). Thus, production of TEP may be critical in providing a source of available carbon to fuel microbial food webs (Azam \& Malfatti 2007), especially in oligotrophic environments (Passow 2002, Beauvais et al. 2003).

The Levantine basin is considered P-limited and ultra-oligotrophic, being characterized by extremely low chlorophyll a ( $\mathrm{chl} a$ ) concentrations and primary production that is dominated by pico-phytoplankton populations. Chl a concentrations are typically $<0.5 \mu \mathrm{g}$ $\mathrm{l}^{-1}$, with a deep ( 80 to $\sim 130 \mathrm{~m}$ ) chl a maximum (DCM). Rates of primary and bacterial productivity are $\sim 0.11$ and $\sim 0.05 \mu \mathrm{g} \mathrm{Cl}^{-1} \mathrm{~h}^{-1}$, respectively (Berman et al. 1984, Li et al. 1993, Tanaka et al. 2007).

Although increasing research attention focuses on the role of TEP and other transparent organic particles in marine ecology (Azam \& Malfatti 2007), as yet there have been few studies on TEP in the Mediterranean Sea (Prieto et al. 2006, Radić et al. 2006). These were mainly conducted in the less oligotrophic western Mediterranean (but see Ortega-Retuerta et al. 2010) and were limited to samples within the euphotic zone. In contrast, the present study was carried out in the extremely oligotrophic Levantine basin with sampling down to $1000 \mathrm{~m}$.

Our premise was that TEP might play an integral role in the cycling of organic matter from the surface to deeper $(1000 \mathrm{~m})$ waters in these ultra-oligotrophic waters. We measured depth and spatial distribution patterns of TEP during 2 east to west transects in the summers of 2008 and 2009 across the ultra-oligotrophic Levantine basin, eastern Mediterranean Sea, and seasonally at 2 stations, 20 and $50 \mathrm{~km}$ offshore, during 2008. From our data, we deduce spatial and seasonal patterns of TEP formation and utilization in the Levantine basin and evaluate the role of TEP in carbon cycling and transport in these waters.

\section{MATERIALS AND METHODS}

Study area and sample collection. Offshore sampling: Offshore water samples were collected during daytime on monthly cruises in 2008 (the February/ March mixed period and the late May/June stratified period) on board the RV 'Mediterranean Explorer'. We sampled 2 stations: a coastal station (T2, $200 \mathrm{~m}$ deep) above the continental shelf and an open-ocean station (T1, $1000 \mathrm{~m}$ deep) off the continental shelf (Table 1, Fig. 1). Water samples were collected for TEP, chl $a_{\text {, }}$ alkaline phosphatase activity (APA), and nutrients (nitrate + nitrite and phosphate) from different depths using Niskin bottles ( 8 l) mounted on a Rosette equipped with a CTD (Seabird 19 Plus), measuring temperature and salinity, and a PAR sensor (photosynthetically active radiation; Biospherical/Licor) for down-welling irradiance.

SESAME cruise: Aboard the RV Shikmona, we sampled 6 stations during September 2008 (stratified period) in the Levantine basin on an east to west transect (Table 1, Fig. 1) within the framework of the Southern European Seas: Assessing and Modeling

Table 1. Geographic locations and bottom depths of sampling stations described in the present study

\begin{tabular}{|c|c|c|c|c|}
\hline \multirow[t]{2}{*}{ Station } & \multicolumn{2}{|c|}{ Location } & \multirow{2}{*}{$\begin{array}{l}\text { Distance from } \\
\text { shore }(\mathrm{km})\end{array}$} & \multirow{2}{*}{$\begin{array}{c}\text { Bottom } \\
\text { depth }(m)\end{array}$} \\
\hline & Lat $^{\circ} \mathrm{N}$ & Long $^{\circ} \mathrm{E}$ & & \\
\hline \multicolumn{5}{|c|}{$\begin{array}{l}\text { Routine sampling, } \\
\text { both stations from Feb to Mar and May to Jun } 2008\end{array}$} \\
\hline $\mathrm{T} 2$ & $34^{\circ} 34.51$ & $32^{\circ} 09.98$ & 20 & 200 \\
\hline $\mathrm{T} 1$ & $34^{\circ} 14.91$ & $32^{\circ} 10.06$ & 51 & 1000 \\
\hline \multicolumn{5}{|c|}{ SESAME cruise, sampling Sep 2008} \\
\hline IL1 & $34^{\circ} 52.03$ & $32^{\circ} 53.58$ & 11.5 & 150 \\
\hline IL2 & $33^{\circ} 09.01$ & $34^{\circ} 08.51$ & 82.1 & 1709 \\
\hline IL4 & $33^{\circ} 00.00$ & $33^{\circ} 14.69$ & 180.9 & 1609 \\
\hline IL9 & $33^{\circ} 29.50$ & $33^{\circ} 28.90$ & 227.8 & 2530 \\
\hline IL13 & $28^{\circ} 30.00$ & $33^{\circ} 40.13$ & 359.3 & 2738 \\
\hline IL20 & $25^{\circ} 00.20$ & $34^{\circ} 00.80$ & 916.2 & 2566 \\
\hline \multicolumn{5}{|c|}{ ISRLEV cruise, sampling Jul 2009} \\
\hline 1 & $34^{\circ} 44.90$ & $32^{\circ} 56.90$ & 24.1 & 1200 \\
\hline 2 & $33^{\circ} 38.90$ & $33^{\circ} 18.90$ & 135.2 & 2000 \\
\hline 3 & $32^{\circ} 14.90$ & $33^{\circ} 41.90$ & 240.4 & 1200 \\
\hline 4 & $29^{\circ} 29.86$ & $34^{\circ} 50.65$ & 555.6 & 3000 \\
\hline 5 & $29^{\circ} 30.75$ & $35^{\circ} 28.98$ & 579.6 & 1200 \\
\hline
\end{tabular}




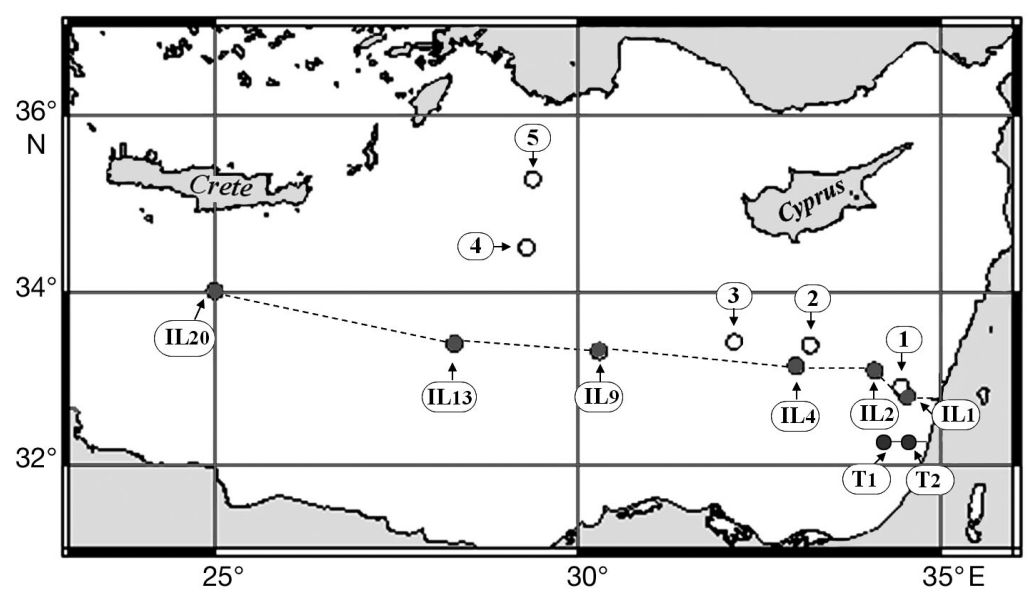

Fig. 1. Eastern Mediterranean Sea. Sampling locations from different cruises: ISRLEV-Stns 1 to 5 (July 2009); SESAME-Stns IL1, IL2, IL4, IL9, IL13 and IL20 (September 2009); and the 2 routine stations west of Herzlia - T1 and T2, which were sampled monthly between January and November 2008

overnight at $60^{\circ} \mathrm{C}$. POC was determined using a Perkin-Elmer Model $240 \mathrm{CHN}$ analyzer after carbonate was removed from the filters by $\mathrm{HCl}$ fumes overnight. Blank pre-combusted filters were used for calibration.

Chl a as an algal proxy. Chl a was measured in duplicate by means of a Turner Designs fluorometer calibrated with pure chl a (Sigma C6144, from Anacystis nidulans). Seawater samples $(300 \mathrm{ml})$ were filtered through Whatman GF/F fiber filters, and pigments were extracted on-board in cold acetone $(90 \%)$ for $24 \mathrm{~h}$ in the dark (HolmHansen et al. 1965).

TEP concentrations, visualization of TEP, and associated bacteria. Water samples $(100 \mathrm{ml})$ were filtered onto $0.4 \mu \mathrm{m}$ polycarbonate filters, and TEP

Ecosystem Change (SESAME) program. At each station, 5 depths were sampled: the surface layer $(\sim 5 \mathrm{~m})$, mid-euphotic zone ( 50 m deep), DCM ( 120 m), below the DCM (300 m), and at depth (1000 m). Samples were analyzed for chl $a$, TEP, POC, and nutrient concentrations.

ISRLEV Cruise: Samples were collected aboard the RV 'Mediterranean Explorer' during July 2009 (stratified period). We sampled 5 stations along an east to northwest transect (Table 1, Fig. 1). Each station was sampled at 5 depths as in the SESAME cruise. On this transect, we measured the same parameters as during the SESAME cruise, with the addition of TEP visualization in the microscope and bacterial productivity (BP).

Nutrient analyses. Triplicate water samples were collected in $15 \mathrm{ml}$ acid-washed plastic scintillation vials. Nutrients were determined using a segmented flow Skalar SANplus System spectrophotometer as detailed in Kress \& Herut (2001). The precision for nitrate + nitrite and dissolved inorganic phosphate (DIP) was 0.02 and $0.003 \mu \mathrm{M}$, respectively, with detection limits of 0.02 and $0.008 \mu \mathrm{M}$, respectively.

Alkaline phosphatase activity (APA). APA was measured fluorometrically with 3-0-methylfluorescein-phosphate (MUF) as a substrate using the method of Ammerman (1993). APA (nmol P $\mathrm{l}^{-1} \mathrm{~h}^{-1}$ ) was calculated by using a linear regression of fluorescence values versus the measured incubation time $\left(\sim 24 \mathrm{~h}\right.$ incubations at $\sim 25^{\circ} \mathrm{C}$ and $\mathrm{pH}$ of 8.2) and correcting the fluorescence values of samples to the blank sterile seawater (SSW) samples (excitation: $364 \mathrm{~nm}$; emission: $448 \mathrm{~nm}$ ).

Particulate organic matter (POC). Seawater (4 l) was filtered through pre-combusted $\left(4 \mathrm{~h}, 450^{\circ} \mathrm{C}\right) \mathrm{GF} / \mathrm{F}$ filters and stored at $-20^{\circ} \mathrm{C}$ until analysis within 1 mo after the cruise. Prior to analysis, the filters were dried concentrations ( $\mu \mathrm{g}$ gum xanthan $[\mathrm{GX}]$ equivalents $\mathrm{l}^{-1}$ ) were measured according to Passow \& Alldredge (1995). We used a conversion factor of 0.51 to convert from micrograms of GX equivalents to micrograms of carbon (Engel \& Passow 2001).

To visualize TEP, samples $(150 \mathrm{ml})$ were filtered gently ( 100 to 150 mbar) onto $0.4 \mu \mathrm{m}$ polycarbonate filters, stained for $10 \mathrm{~s}$ with freshly prepared, $0.2 \mu \mathrm{m}$ pre-filtered Alcian Blue (AB) solution (0.02\%), and rinsed with $5 \mathrm{ml}$ of double distilled water (DDW). The filter was then stained with $30 \mu \mathrm{l}$ DAPI $(250 \mu \mathrm{g}$ $\mathrm{ml}^{-1}$ ) for $12 \mathrm{~min}$ in the dark and rinsed with $5 \mathrm{ml}$ DDW to remove excess DAPI (Passow \& Alldredge 1995). The filter was then placed on a coated Cytoclearslide (Clearing Slides, GE Osmonics Lab store) with $10 \mu \mathrm{l}$ of glutaraldehyde $(0.5 \%)$ to fix the sample and a drop of immersion oil, and was covered with a cover slip. Slides were kept in a dark, humid container until examined at the laboratory. TEP images were taken under bright-field (Nomarski) illumination; bacteria were visualized with an UV epifluorescent microscope (Nikon 80i microscope) equipped with a specific DAPI filter (excitation: $350 \mathrm{~nm}$; emission: $450 \mathrm{~nm}$ ).

Bacterial production. In the present paper we use the term 'bacteria' to include both bacteria and archaea within the microbial population. BP was estimated using the ${ }^{3} \mathrm{H}$-leucine incorporation method (Kirchman et al. 1985, Simon \& Azam 1989) as modified by Smith \& Azam (1992). Triplicate $(1.7 \mathrm{ml})$ samples were incubated with $200 \mathrm{nmol} \mathrm{l}^{-1}$ of ${ }^{3} \mathrm{H}$-leucine (Amersham; specific activity: $160 \mathrm{Ci} \mathrm{mmol}^{-1}$ ) for a period lasting from 4 to $14 \mathrm{~h}$ at in situ $\left(\sim 25^{\circ} \mathrm{C}\right)$ temperatures in the dark. (Preliminary experiments indicated that this was a saturating level of ${ }^{3} \mathrm{H}$-leucine and that 
incorporation was linear during this time period.) Trichloroacetic acid (TCA)-killed samples served as zero time controls. The incorporation was stopped with the addition of $100 \mu \mathrm{l}$ of cold $100 \%$ TCA to the vials, and samples were kept at $4{ }^{\circ} \mathrm{C}$ until processing, which was carried out several days after the cruise. After addition of $1 \mathrm{ml}$ scintillation cocktail (Sigma No. 1008300), the samples were counted in a scintillation counter (Tri-Carb 2100TR Packard). Leucine incorporation was converted to BP using a factor of $3.1 \mathrm{~kg} \mathrm{C} \mathrm{mol}{ }^{-1}$ with an isotope dilution factor of 2.0 (Smith \& Azam).

\section{RESULTS \\ Distribution of TEP under mixed and stratified conditions}

To follow seasonal changes in TEP depth distribution, 2 pelagic stations close to the Israeli coast (T2 and T1) were sampled in the winter and summer of 2008. During winter mixing (February to March), the season with generally the highest phytoplankton standing stocks, temperature $\left(18 \pm 1.4^{\circ} \mathrm{C}\right)$, salinity $(39.35$ $\pm 0.5 \mathrm{psu}$ ), chl a (range: 0.12 to $0.99 \mu \mathrm{g} \mathrm{l} \mathrm{l}^{-}$ ${ }^{1}$ ), TEP (range: 120 to $290 \mu \mathrm{g} \mathrm{GX}{ }^{-1}$ on different sampling dates) and APA (0.5 \pm 0.05 MUF $n M h^{-1}$ ) were uniformly distributed down to $\sim 200 \mathrm{~m}$ (mean $\pm \mathrm{SD}$ ) (Fig. 2A,B).

During the stratified period (May through June) the water column was characterized by high surface temperatures $\left(24 \pm 3^{\circ} \mathrm{C}\right)$, with a sharp thermocline at $\sim 150 \mathrm{~m}$ at both stations (representative data from Stn T2 are shown in Fig. 2C, D). The euphotic depth (taken as $0.1 \%$ surface irradiance) reached $\sim 150 \mathrm{~m}$. Chl a concentrations were low in near-surface waters $(0.02$ to $\left.0.1 \mu \mathrm{g} \mathrm{l}^{-1}\right)$, with a $\operatorname{DCM}(0.27 \pm$

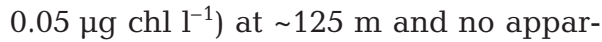
ent algal bloom. TEP concentrations were maximal near-surface (225 to

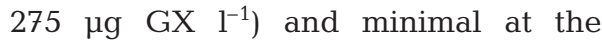

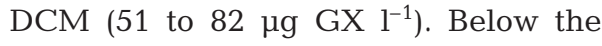
DCM, TEP concentrations increased with depth to $200 \mathrm{~m}$ (100 to $132 \mu \mathrm{g}$ GX $\mathrm{l}^{-1}$ ). Significantly higher rates of APA were measured near the surface, 0 to $10 \mathrm{~m}\left(1.4 \pm 0.5 \mathrm{nM} \mathrm{MUF} \mathrm{h}^{-1}\right)$, than at $200 \mathrm{~m}\left(0.2\right.$ to $\left.0.4 \mathrm{nM} \mathrm{MUF} \mathrm{h}^{-1}\right)$.
During the stratified period, both TEP and APA exhibited significant correlations with chl a (Fig. 3). A significant negative correlation $\left(\mathrm{R}^{2}=0.48, \mathrm{p}=\right.$ $0.004, \mathrm{n}=14$ ) was found between TEP and chl $a$, while a significant positive correlation $\left(\mathrm{r}^{2}=0.71, \mathrm{p}=\right.$ $0.0002, \mathrm{n}=14$ ) was found between TEP and APA (Fig. 3A,B). During winter mixing, no such correlations were obtained between the different parameters.
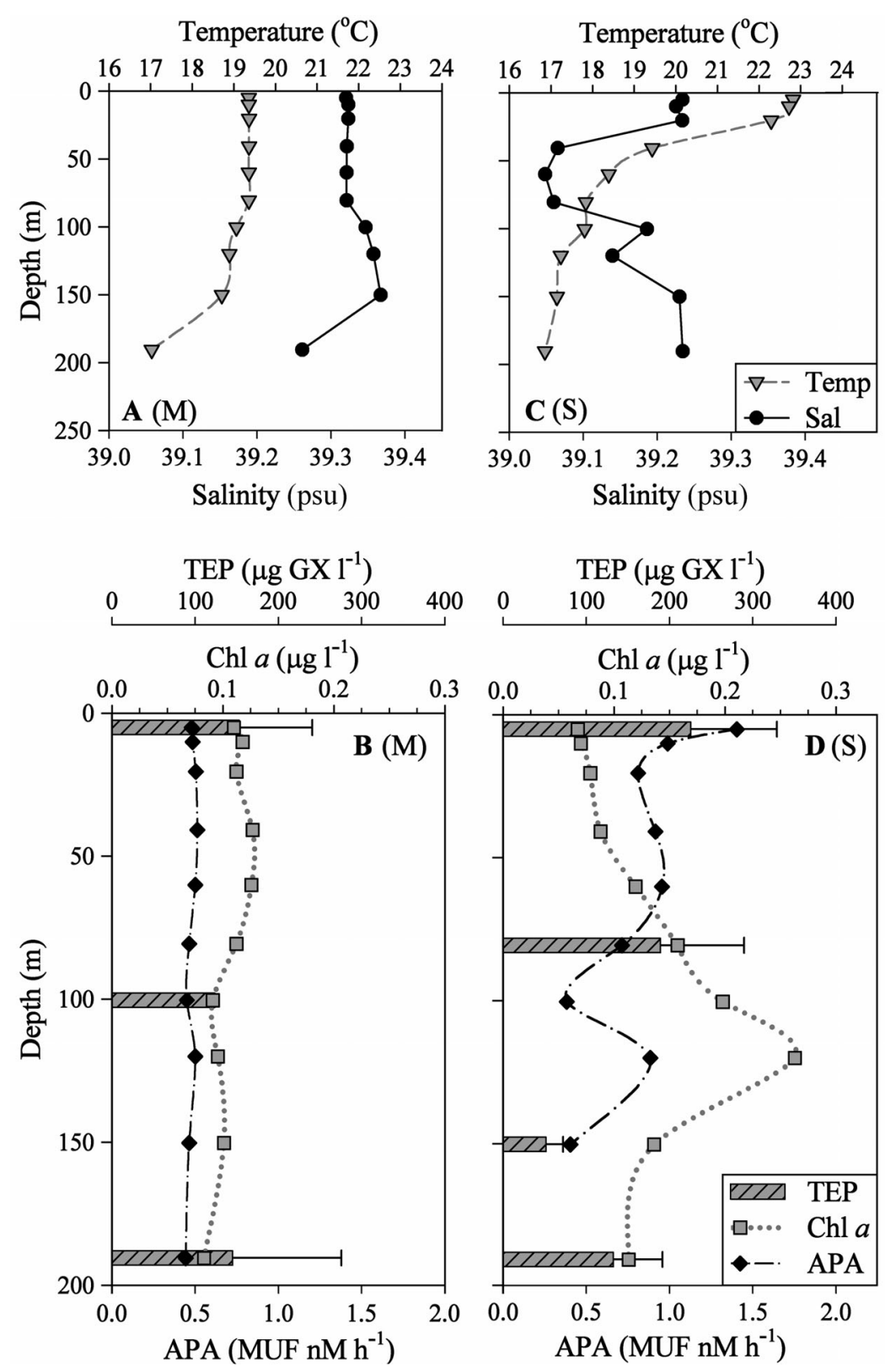

Fig. 2. Representative depth profiles sampled during the mixed, $M$, period $(A, B)$ and the stratified, $S$, period $(C, D)$ from Stn T2. $(A, C)$ temperature $(\nabla)$ and salinity $(\Theta)$. (B,D) transparent exopolymer particles (TEP, bars), chlorophyll a (chl $a$ ), and alkaline phosphatase activity (APA $\bullet$ ). GX: gum xanthan; MUF: 3-0-methylfluorescein-phosphate 

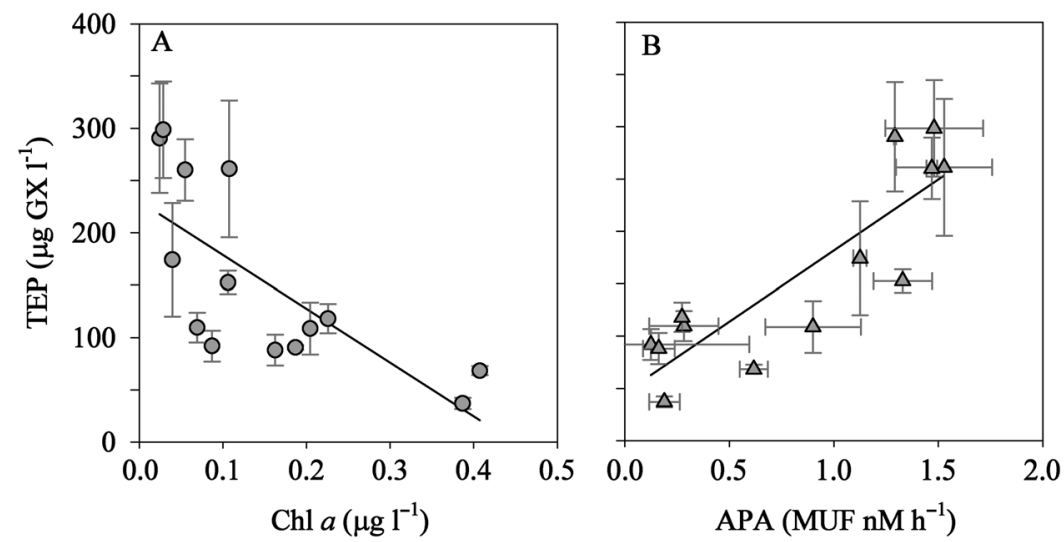

Fig. 3. Relationship (Pearson correlation test) between transparent exopolymer particles (TEP), chlorophyll a (chl a), and alkaline phosphatase activity (APA) (data from monthly sampling at Stns T1 and T2). Linear regression is shown of: (A) TEP versus chl a $\left(\mathrm{r}^{2}=0.48, \mathrm{p}=0.004, \mathrm{n}=14\right)$ and (B) TEP versus APA $\left(\mathrm{r}^{2}=0.71, \mathrm{p}=0.0002, \mathrm{n}=14\right)$. All means $\pm \mathrm{SD}$

\section{Spatial distribution of TEP and chlorophyll in the Levantine basin}

Data obtained during 2 transects across the Levantine basin (SESAME and ISRLEV), made during the stratified summer seasons of 2008 and 2009, respectively, enabled us to generate a more comprehensive view of the role of TEP in these waters. Sea-surface temperatures in summer ranged from 25 to $29^{\circ} \mathrm{C}$.In both transects, nitrate + nitrite and phosphate concentrations were extremely low in the euphotic zone $(\sim 0.1$ and $\sim 0.02 \mu \mathrm{M} \mathrm{N}$, respectively). Integrated concentrations (to $200 \mathrm{~m}$ ) of nitrate + nitrite and DIP (35.4 to 330.2 and 1.4 to $11.3 \mu \mathrm{M} \mathrm{m}^{-2}$, respectively) showed a decreasing gradient (i.e. increasingly oligotrophic conditions) from west to east that was significantly correlated with distance from shore (E. Rahav pers. comm.).

Phytoplankton standing stocks were minimal during the summer, with no apparent algal bloom. Thus, chl a concentrations were extremely low, but nevertheless decreased from 0.07 to $0.03 \mu \mathrm{g} \mathrm{l}^{-1}$ from west to east, indicative of a gradient of rising oligotrophy. A significant positive correlation between chl a and distance from the Israeli coast was observed for surface and DCM samples (Fig. 4).

The relationship between TEP and trophic status of the phytoplankton (using chl a as a proxy) with distance from the Israeli shore was examined at 3 key depths; near the surface (5 to $80 \mathrm{~m})$, the DCM ( 120 m) and in deep water (300 to $1000 \mathrm{~m}$ ) across the Levantine basin. Significant, negative correlations between TEP concentrations and distance from shore were observed for near-surface and deep waters $\left(r^{2}=0.62\right.$, $\mathrm{p}=0.003, \mathrm{n}=9$ and $\mathrm{r}^{2}=0.72, \mathrm{p}=0.004, \mathrm{n}=10$, respectively). No significant relationships were found between TEP and distance from shore at the DCM.

\section{Depth distribution of TEP and related parameters}

In Table 2 we list the average, nearsurface $(5 \mathrm{~m})$ concentrations of TEP, chl $a$, and $\mathrm{POC}$, and the rates of $\mathrm{BP}$ across the Levantine basin based on data from both the SESAME (September 2008) and ISRLEV (July 2009) cruises. Averaged depth profiles of TEP, BP, POC, and chl a are shown in Fig. 5 and Table 2.

During these cruises, irradiance was very high $\left(\sim 1400 \mu \mathrm{mol}\right.$ quanta $\left.\mathrm{m}^{-2} \mathrm{~s}^{-1}\right)$ at $5 \mathrm{~m}$ depth across the Levantine basin, while nutrients and chl a concentrations were extremely low (nitrate + nitrite: $\sim 0.1 \mu \mathrm{M}$; phosphate: $\sim 0.02 \mu \mathrm{M}$; chl a: 0.04 to $\left.0.07 \mu \mathrm{g} \mathrm{l}^{-1}\right)$. A consistent peak of chl a $\left(\sim 0.32 \mu \mathrm{g} \mathrm{l}^{-1}\right)$ was observed in the DCM located at $\sim 120 \mathrm{~m}$ (Table 2, Fig. 5).

The highest concentrations of TEP ranging from

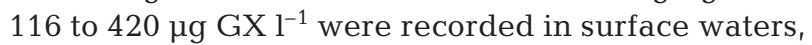
while minimum TEP concentrations, 48 to $189 \mu \mathrm{g}$ GX $\mathrm{l}^{-1}$ (about $40 \%$ of the near-surface values) were consistently observed in the DCM $(\sim 120 \mathrm{~m})$. At greater depths (300 to $1000 \mathrm{~m})$, TEP concentrations increased again to about $70 \%$ of near-surface values, ranging between 83 and $386 \mu \mathrm{GX}^{-1}$ (Fig. 5).

The highest levels of BP (0.3 to $\left.2.5 \mu \mathrm{g} \mathrm{C}^{-1} \mathrm{~d}^{-1}\right)$ were also detected in the surface waters. BP decreased by $\sim 70 \%$ in the mid-euphotic zone $(60 \mathrm{~m})$, but increased to $40 \%\left(\sim 0.9 \mu \mathrm{g} \mathrm{C}^{-1} \mathrm{~d}^{-1}\right)$ in the DCM. Below the DCM, $\mathrm{BP}$ levels were low, with minima at 200 and $1000 \mathrm{~m}$.

\section{Visualization of TEP in the water column}

Microscopic images of TEP from near-surface samples frequently showed large $(176 \pm 105 \mu \mathrm{m}$ maximum length $\pm \mathrm{SD}$ ) AB-stained material sloughing off from various algal cells, as well as detached sheet-like material (Figs. 6A,B \& 7). Although we found no significant correlation between TEP and BP at any of the depths sampled (data not shown), some of these particles appeared to be heavily colonized by bacteria (Fig. 6A,B).

In samples from the DCM, most TEP were much smaller, $4.4 \pm 4 \mu \mathrm{m}$ (maximum length $\pm \mathrm{SD}$ ) and more irregular in shape than those from near the surface (Figs. 6C \& 7). Bacteria were only occasionally associated with these TEP (Fig. 6C).

TEP from $1000 \mathrm{~m}$ tended to be of an irregular, amorphous shape and larger $(60 \pm 33 \mu \mathrm{m}$, maximum length $\pm \mathrm{SD}$ ) than in DCM samples (Figs. 6D \& 7). Bacteria almost always appeared to be associated with these particles (Fig. 6D). 


\section{TEP carbon in relation to total POC}

Across the pelagic Levantine basin, POC concentrations varied from 12 to $250 \mu \mathrm{g} \mathrm{Cl}^{-1}$. In contrast to TEP and chl $a$, POC did not correlate with distance from

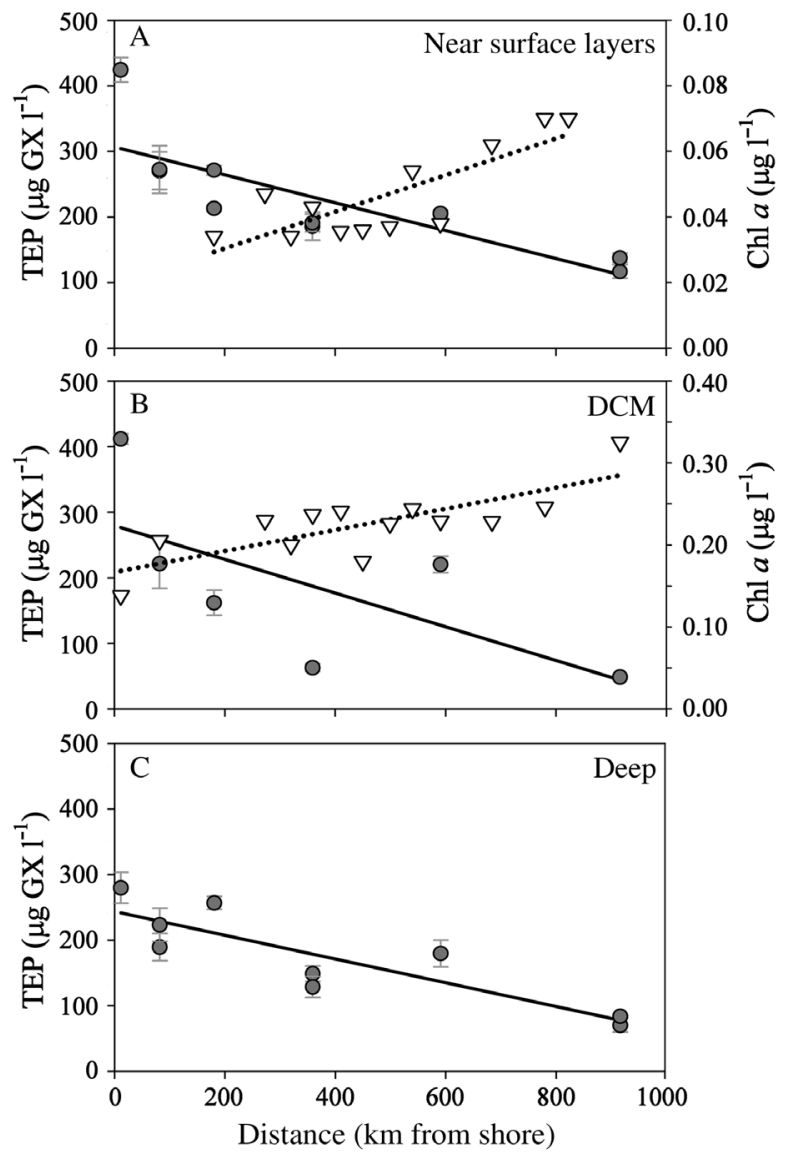

Fig. 4. Relationship between transparent exopolymer particles (TEP, 0 ) and chlorophyll $a(\mathrm{chl} a, \nabla)$ concentrations (means $\pm \mathrm{SD}$ ) and the distance from shore; SESAME and ISRLEV transects: (A) 5 to $80 \mathrm{~m}$ depth. TEP: $\mathrm{r}^{2}=0.62, \mathrm{p}=$ $0.004, \mathrm{n}=9$; chl $a: \mathrm{r}^{2}=0.615, \mathrm{p}=0.0002, \mathrm{n}=12$. (B) Deep chlorophyll maximum (DCM). TEP: $\mathrm{r}^{2}=0.3, \mathrm{p}=0.15, \mathrm{n}=6$; chl $a$ : $\mathrm{r}^{2}=0.57, \mathrm{p}=0.002, \mathrm{n}=13$. (C) 250 to $1000 \mathrm{~m}$. TEP:

$$
\mathrm{r}^{2}=0.72, \mathrm{p}=0.003, \mathrm{n}=10
$$

Table 2. Surface $(5 \mathrm{~m})$ concentrations of transparent exopolymer particles (TEP), chlorophyll a (chl a), particulate organic carbon (POC) and the rates of bacterial productivity (BP) from the eastern Levantine basin (all means \pm SD). Values were averaged from replicated measurements at $5 \mathrm{~m}$ from different stations (n: number of stations). These average values were then used to represent the $100 \%$ baseline for each parameter plotted in Fig. 7. GX: gum xanthan

\begin{tabular}{|lcc|}
\hline Parameter & Concentration or rate & $\mathrm{n}$ \\
\hline TEP $\left(\mu \mathrm{g} \mathrm{GX}^{-1}\right)$ & $345 \pm 143.2$ & 12 \\
$\mathrm{Chl} a\left(\mu \mathrm{g} \mathrm{l}^{-1}\right)$ & $0.04 \pm 0.01$ & 12 \\
$\mathrm{BP}\left(\mu \mathrm{C} \mathrm{l}^{-1} \mathrm{~d}^{-1}\right)$ & $2.24 \pm 0.86$ & 5 \\
POC $\left(\mu \mathrm{C} \mathrm{l}^{-1}\right)$ & $165 \pm 38$ & 7 \\
\hline
\end{tabular}

shore for any of the sampled depths and did not exhibit any significant west-east gradient.

To estimate TEP carbon content (TEP-C) we used the lowest TEP ( $\left.\mu \mathrm{g} \mathrm{GX} \mathrm{l}^{-1}\right)$ to $\mathrm{C}\left(\mu \mathrm{gl}^{-1} \mathrm{C}\right)$ conversion factor (0.51) suggested by Engel \& Passow (2001). Based on this conversion factor, we estimated concentrations of TEP-C ranging from 38 to $178 \mu \mathrm{g} \mathrm{C} \mathrm{l}^{-1}$. Thus, at all stations sampled, a substantial portion of POC appeared to consist of TEP-C. At near-surface depths, TEP-C contributed $63 \pm 3 \%$ of the total POC, increasing to $83 \pm 36.6 \%$ at the DCM, with large variability between different sampling stations. In deeper waters, we obtained an apparent value for TEP-C that was $>100 \%$ of the measured POC pool. A significant $\left(\mathrm{r}^{2}=0.5, \mathrm{p}=0.003, \mathrm{n}=14\right)$ negative correlation was observed between POC $\left(\mu \mathrm{C} \mathrm{Cl}^{-1}\right)$ and TEP $\left(\mu \mathrm{g} \mathrm{GX} \mathrm{l^{-1 }}\right)$ concentrations for all stations and depths measured (Fig. 8).

\section{DISCUSSION}

Within the voluminous literature on TEP, relatively few reports document TEP concentrations in the pelagic of different seas (Table 3 and references therein). These show considerable range in TEP concentrations between oceanic regions, with large variability and impact on carbon cycling attributed to spatial, temporal, and depth factors (Table 3). Most investigations to date have examined TEP variability only within the upper photic zone, and we are not aware of any published studies of TEP levels in deeper water $(>200 \mathrm{~m})$. Also, to the best of our knowledge, no studies from extreme oligotrophic environments showing the depth, spatial, and seasonal distribution of TEP have yet been published.

Our results from the ultra-oligotrophic Levantine basin show a large spatial and temporal variability of both TEP morphology and concentrations. TEP concentrations in the present study varied from 19 to $600 \mu \mathrm{g} \mathrm{GX} 1^{-1}$, which is within the range of 23 to $791 \mu \mathrm{g} \mathrm{GX} \mathrm{l}^{-1}$ of TEP reported from many marine environments (Table 3 ).

\section{Seasonal changes of TEP concentrations in an ultra- oligotrophic environment}

The release of mucoid substances such as TEP from phytoplankton is often the result of seasonal changes in irradiance and nutrient availability (Passow 2002, Berman-Frank et al. 2007). At the offshore stations (T1 and T2), there were marked differences in nutrient (nitrate + nitrite and DIP) concentrations in near-surface waters between the mixed and strati- 

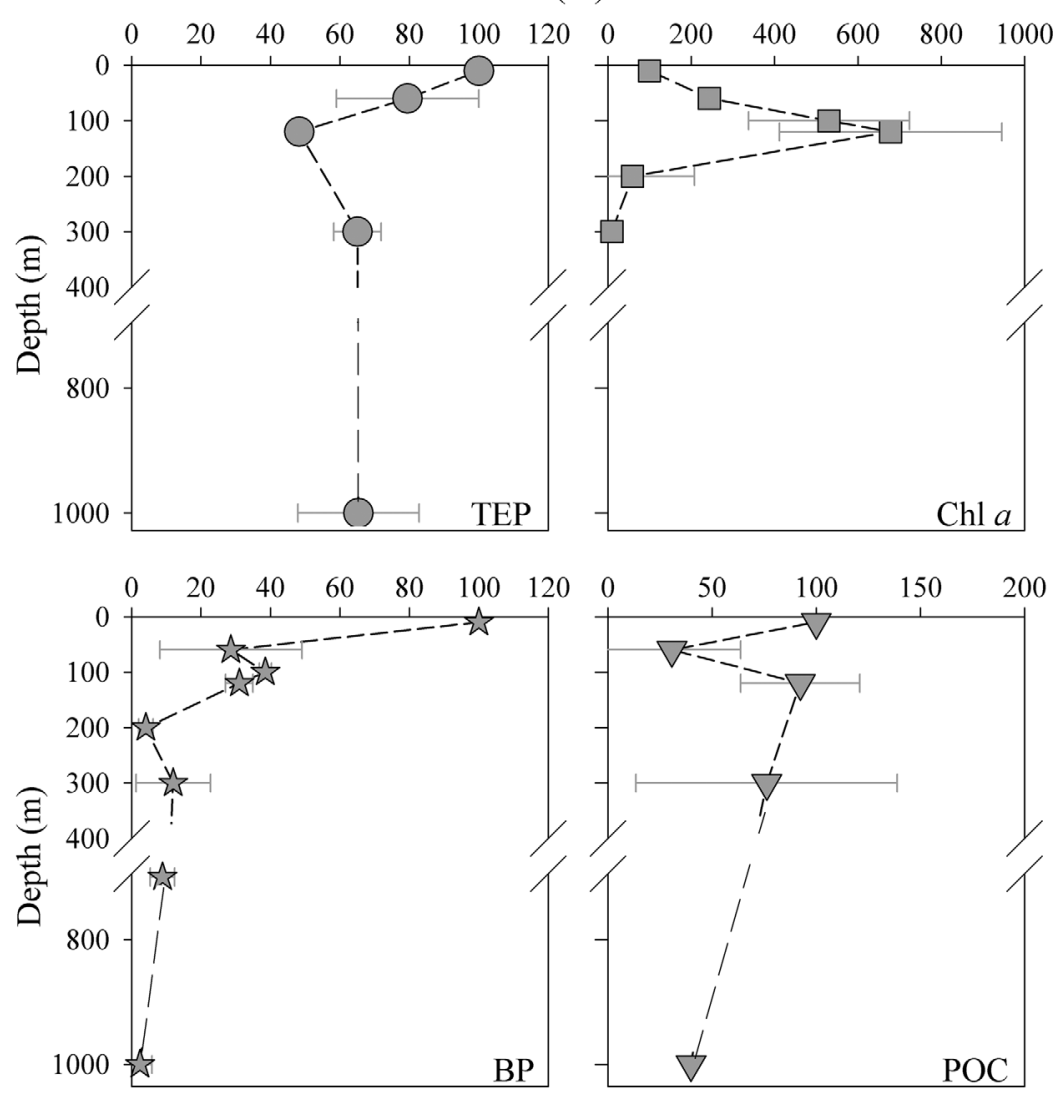

Fig. 5. Representative depth profiles (averaged from data measured at 7 stations during the SESAME and ISRLEV cruises) of transparent exopolymer particles (TEP), chlorophyll a ( $\mathrm{chl}$ a), bacterial productivity (BP), and particulate organic carbon (POC), normalized to surface $(5 \mathrm{~m})$ samples taken as $100 \%$. Actual concentrations and rates are given in Table 2. Means \pm SD

In contrast, during the mixed period when the annual phytoplankton bloom occurred, upwelling of nutrient-rich, deep water resulted in a sharp drop of APA rates, indicating a relaxation in $\mathrm{P}$ stress. With sufficient nutrients and adequate irradiance, a tight coupling between photosynthetic carbon uptake and incorporation into biomass would limit the amount of TEP produced as excess carbon (Berman-Frank \& Dubinsky 1999). Thus, during the mixed season, no significant correlations were found between TEP and chl $a$ or between TEP and APA.

\section{Spatial TEP distribution during the stratified season}

Our measurements covering a transect of the pelagic Levantine basin during 2 stratified summer periods (SESAME and ISRLEV) demonstrated that TEP concentrations in the euphotic zone increased from west to east (Table 1), as contrasted with declining chl a (Fig. 4). Nutrient (N, P) concentrations also indicated increasing oligotrophy from west to east in the Mediterranean and the Levantine basin (Harris et al. 2001, Tanaka et al. 2007, Rahav pers. comm.). The inverse relationship between chl $a$ and TEP observed during the stratified season across the Lev-

fied seasons; these influenced the levels of chl $a_{\text {, }}$ APA, and TEP (Fig. 2). During the stratified period, high APA rates, indicative of $\mathrm{P}$ stress in both bacteria and phytoplankton, were measured in the nearsurface layer. Limited P availability, combined with high solar irradiance, probably led to an uncoupling in the phytoplankton of photosynthetic carbon uptake and the release of 'excess carbon' as TEP, with algal biomass remaining low (Berman-Frank \& Dubinsky 1999, Corzo et al. 2000). The relationships found between APA, chl $a$, and TEP concentrations over the course of sampling at Stns T1 and T2 were compatible with this scenario (Fig. 3A,B). TEP and APA were significantly positively correlated (Fig. 3B), suggesting that increasing amounts of TEP were released when $\mathrm{P}$ stress increased. Likewise, the significant negative correlation between TEP and chl $a$ (Fig. 3A) may imply that an increasingly stressed, low biomass of phytoplankton released greater amounts of TEP. antine Basin (Fig. 2) is consistent with the idea that nutrient limitation enhanced TEP release from phytoplankton (Fig. 3). Increased release and subsequent sedimentation of TEP and larger TEP-mediated aggregates in the euphotic zone of the Levantine basin during summer stratification when nutrient limitation is maximal could provide an important source of POC and other material that would be available for microorganisms in deeper waters (Engel 2004, Beauvais et al. 2006, Patara et al. 2009).

\section{Depth distribution of TEP: particle formation, utilization, and carbon cycling in the Levantine basin}

To obtain an overview of the depth distribution of TEP, chl $a$, and BP, we averaged the values of these parameters measured at each depth (normalized to the $5 \mathrm{~m}$ sample taken as $100 \%$ ) for all pelagic stations of the SESAME and ISRALEV cruises (Fig. 5). We used 

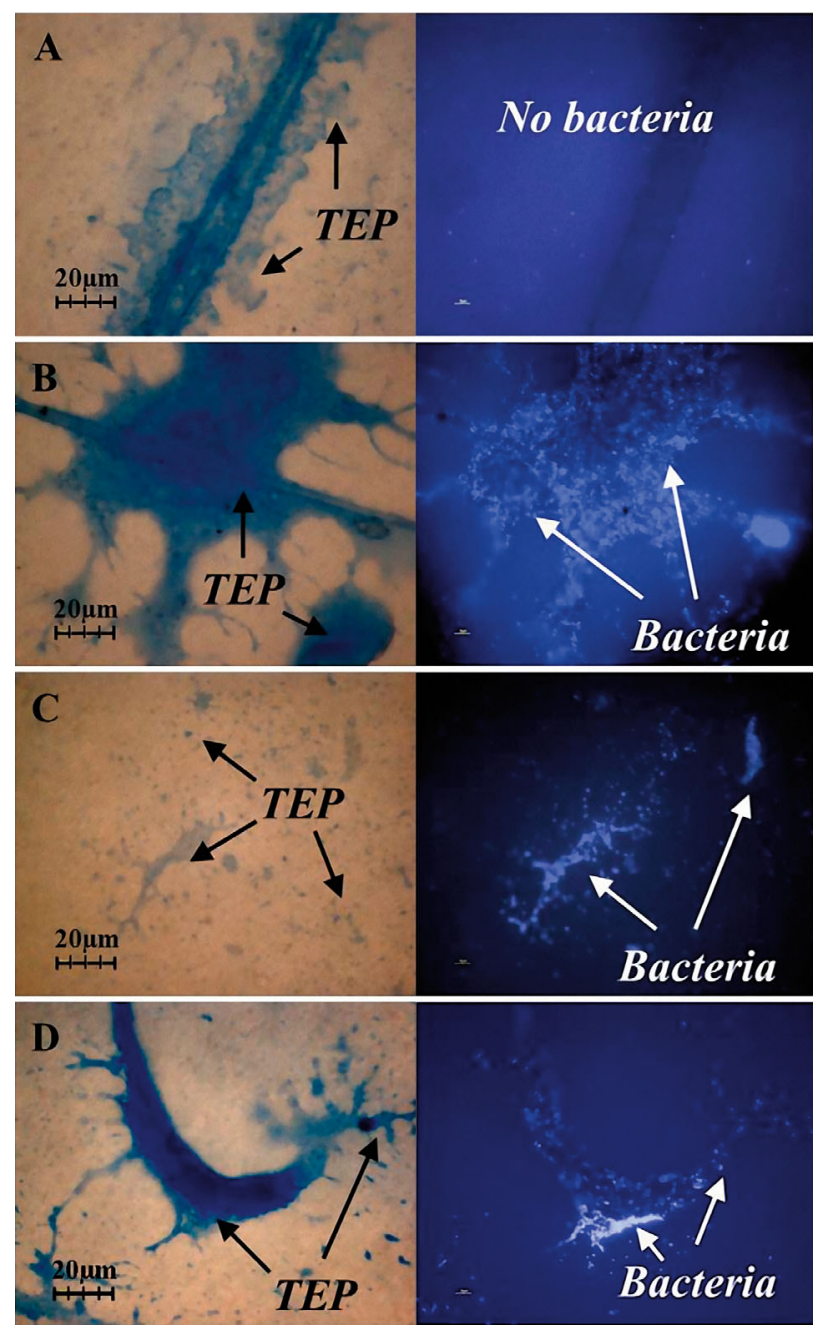

Fig. 6. Microscopic visualization of transparent exopolymer particles (TEP; stained with Alcian Blue, using bright field microscopy) and bacteria (stained with DAPI, using epifluorescent microscopy). Samples from the ISRLEV cruise: (A \& B) from $5 \mathrm{~m},(\mathrm{C})$ from the deep chlorophyll maximum, and (D) from $1000 \mathrm{~m}$

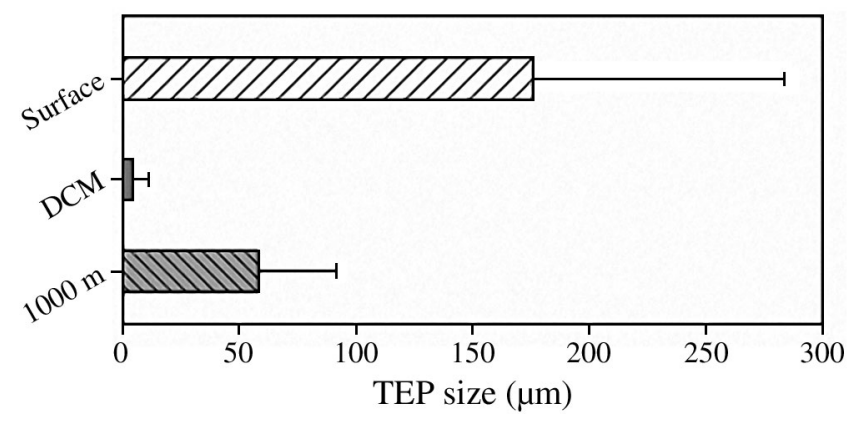

Fig. 7. Size distribution of transparent exopolymer particles (TEP; determined according to axis of maximum length) at different depths from all pelagic stations. Surface: $\mathrm{n}=35$; deep chlorophyll maximum (DCM): $\mathrm{n}=196$; and $1000 \mathrm{~m}$ : $\mathrm{n}=22$. Means $\pm \mathrm{SD}$

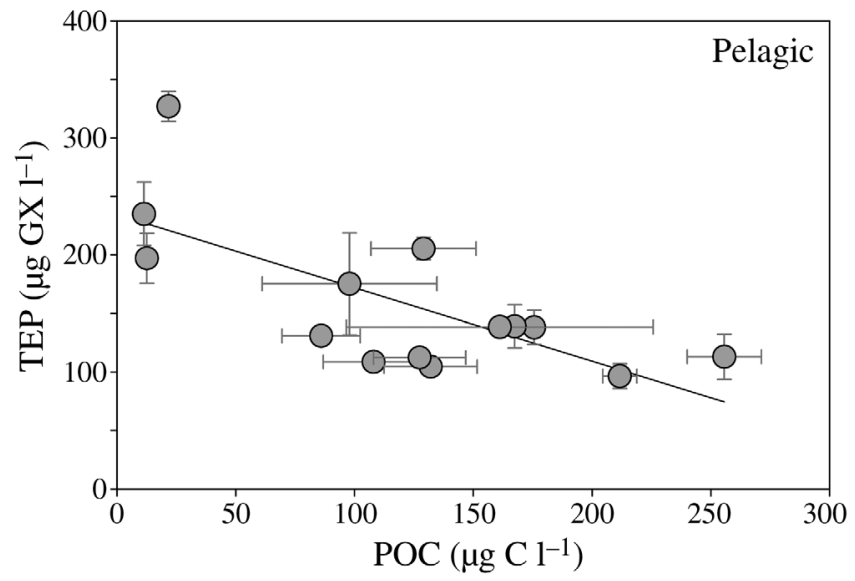

Fig. 8. Relationship between transparent exopolymer particles (TEP) and particulate organic carbon (POC) $\left(r^{2}=0.5, p=\right.$ $0.003, \mathrm{n}=14 ;$ Pearson correlation test). Means $\pm \mathrm{SD}$

these profiles together with the microscopic images of TEP to infer a generalized account of the role of these particles in organic carbon cycling in the Levantine Basin during the stratified period (summarized in Fig. 9).

\section{Euphotic zone (0 to $120 \mathrm{~m})$}

Maximum concentrations of TEP in the water column were consistently observed in the upper euphotic zone. TEP images from these depths showed mostly large (mean $\pm \mathrm{SD}: 176 \pm 105 \mu \mathrm{m}$ ) sheet-like AB-stained particles that frequently appeared to be sloughing off from different micro-phytoplankton cells (Fig. 6A,B). Bacteria and bacterial colonies were associated with these large TEP in $>50 \%$ of the microscopically visualized images from these depths. The high BP rates measured at these depths may have resulted both from bacterial utilization of readily available DOC directly released by phytoplankton and from bacterial growth on TEP substrates (Azam \& Malfatti 2007). We deduced from our data that most of the TEP in the upper photic zone was derived from direct release by phytoplankton and bacteria, from cellular mucoid envelopes or other detrital material, rather than by abiotic self-assembly from colloid precursors (Verdugo \& Santschi 2010). These TEP may then have formed 'hot spots' of microbial metabolic activity fueling the microbial loop, as well as aggregating further to produce marine snow (Verdugo et al. 2004, Azam \& Malfatti 2007, Verdugo \& Santschi 2010).

Intense bacterial activity, combined with microplankton grazing, may have promoted breakdown of large TEP as they sedimented down through the euphotic water column and could explain the decrease 
Table 3. Concentrations of transparent exopolymer particles (TEP) reported from different pelagic environments. n: no. of samples

\begin{tabular}{|c|c|c|}
\hline Sample area & TEP $\left(\mu \mathrm{g} \mathrm{GX} \mathrm{^{-1 } )}\right.$ & Source \\
\hline \multicolumn{3}{|l|}{ Pacific } \\
\hline Monterey Bay & $50-310, n=18$ & Passow \& Alldredge (1995) \\
\hline Great Barrier Reef & $23-791, \mathrm{n}=14$ & Wild (2000) \\
\hline East Sound & $73-159, \mathrm{n}=50$ & Kiørboe et al. (1996) \\
\hline \multicolumn{3}{|l|}{ Atlantic } \\
\hline $\mathrm{NE}$ Atlantic, $47^{\circ} \mathrm{N}$ & $27-279$ & Engel (2004) \\
\hline \multicolumn{3}{|l|}{ South Sea } \\
\hline Antarctic Peninsula & $15.4(0-48.9)$ & Ortega-Retuerta et al. (2009) \\
\hline Ross Sea & $308-2800$ & Hong et al. (1997) \\
\hline \multicolumn{3}{|l|}{ Red Sea } \\
\hline Gulf of Aqaba & $25-230, n=16$ & Bar Zeev et al. (2009) \\
\hline \multicolumn{3}{|l|}{ Mediterranean Sea } \\
\hline Gulf of Cadiz & $100-600$ & García et al. (2002) \\
\hline Straits of Gibraltar & 41-296 & Prieto et al. (2006) \\
\hline Alboran Sea & $<25-539, \mathrm{n}=13$ & Prieto et al. (2006) \\
\hline $\begin{array}{l}\text { Northern Adriatic } \\
\text { (mucus event) }\end{array}$ & $4-14800$ & Radić et al. (2005) \\
\hline $\begin{array}{l}\text { Mediterranean Sea } \\
\text { (without Levantine basin) }\end{array}$ & $4.5-94.3, \mathrm{n}=123$ & Ortega-Retuerta et al. (2010) \\
\hline Levantine basin & $19-600, n=72$ & Present study \\
\hline
\end{tabular}

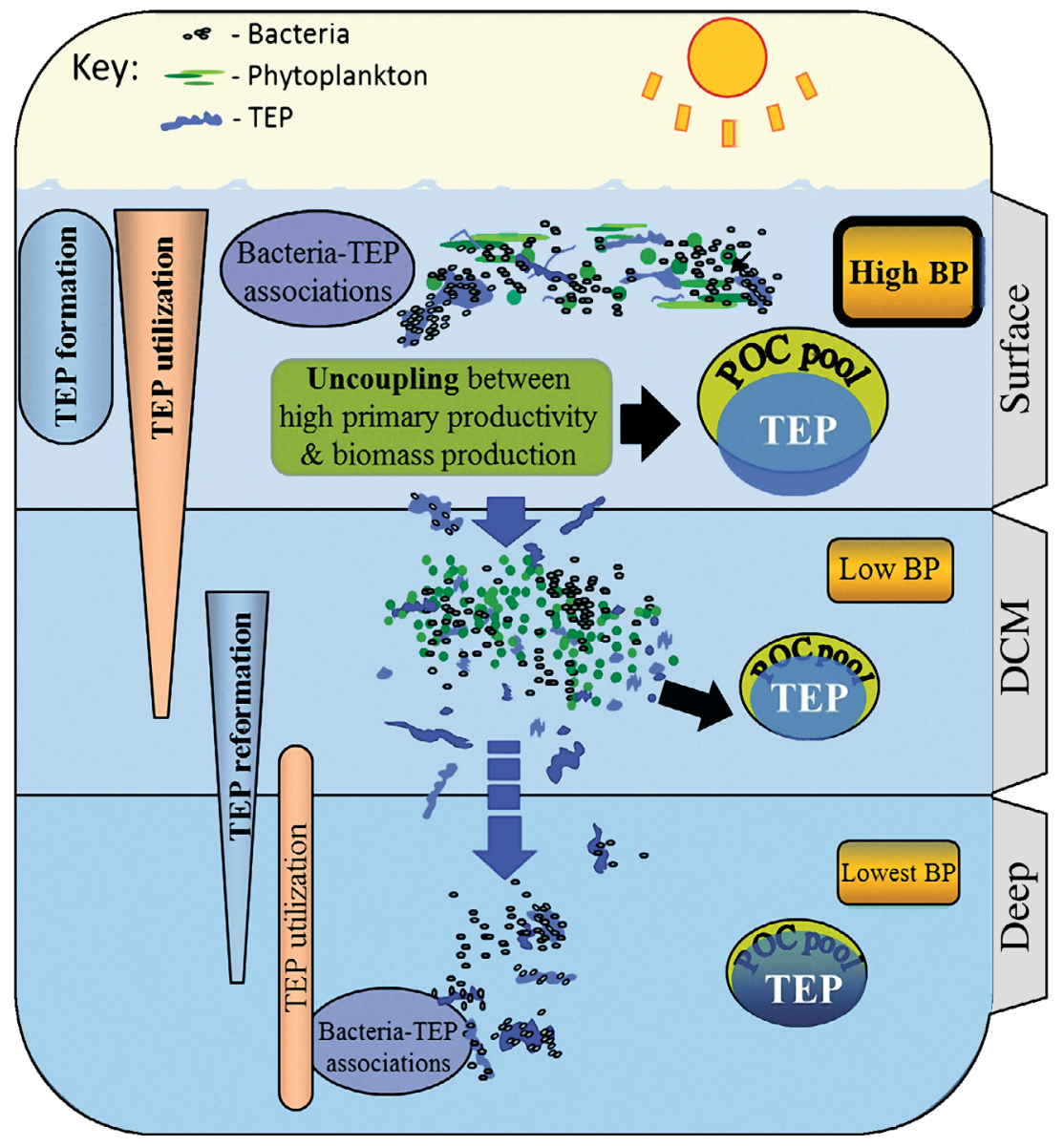

of TEP concentrations with depth towards the DCM observed at all SESAME and ISRLEV stations (Fig. 5). Ortega-Retuerta et al. (2010) reported a similar pattern of TEP depth distribution in the upper $200 \mathrm{~m}$ of nearby regions in the eastern Mediterranean.

\section{DCM (110 to $130 \mathrm{~m})$}

Within the DCM slightly higher ambient DIP and nitrate + nitrite concentrations $(\sim 0.25$ and $\sim 3.75 \mu \mathrm{M}$, respectively) facilitated the growth of a low-light ( 0.1 to $1 \%$ surface irradiance) adapted pico-planktonic, autotrophic community dominated mainly by Synechococcus spp. and Prochlorococcus spp. (data not shown). Across the Levantine basin, TEP concentrations were minimal at the DCM (Fig. 5) and were comprised of mostly small (0.5 to

Fig. 9. Schematic model of transparent exopolymer particles (TEP) formation and utilization in the oligotrophic open ocean under stratified conditions. In the upper photic zone, nutrient-stressed phytoplankton release large amounts of TEP in addition to dissolved organic carbon (DOC). Bacteria exploit TEP-C and extracellularly released DOC effectively; thus bacterial productivity (BP) is also high. As TEP settles to the deep chlorophyll maximum (DCM), they are degraded by bacterial utilization and micro-zooplankton grazing. At the DCM, TEP concentrations are minimal and $\mathrm{BP}$ is also much lower than in the upper euphotic zone. TEP (perhaps derived from pico-phytoplankton and bacteria) are very small and with few associated bacteria. With increasing depth below the DCM, aggregation of colloidal precursors and previously formed TEP lead to greater concentrations of these particles. Below $300 \mathrm{~m}$, TEP appear as large amorphous particles, some with associated bacteria. At these depths BP is very low, presumably due to a lack of readily available substrates. Size of arrows, squares, and ellipses are proportional to their relative importance, with TEP contribution to the particulate organic carbon (POC) pools at the different depths designated by ellipses 
$4 \mu \mathrm{m})$ sized TEP, as visualized and measured microscopically (Figs. 6C \& 7).

The TEP minimum at the DCM may have resulted from a shift in the amount of extracellular TEP released from larger ( 2 to $\sim 40 \mu \mathrm{m}$ ) near-surface phytoplankton to that produced by predominantly small (1 to $2 \mu \mathrm{m}$ ) pico-phytoplankton growing under conditions of tight coupling between photosynthesis and assimilation of carbon into biomass (Tanaka et al. 2007, Rahav pers. comm.). We suggest much of the TEP in the DCM was formed from abiotic self-assembly of smaller precursors (Verdugo \& Santschi 2010). Because we measured only the concentrations of TEP retained on $0.4 \mu \mathrm{m}$ filters (see 'Materials and methods'), we were unable to determine the concentrations of any precursor pool of smaller $(0.05$ to $0.4 \mu \mathrm{m}$ ), colloidal-sized TEP (Villacorte et al. 2010) that may have been significant at these depths.

Very few bacteria were associated with the small TEP at the DCM (Fig. 6), indicating that these particles did not offer a suitable substrate for bacterial colonization (Passow 2002) and possibly explaining the low measured BP rates (Fig. 5). Additionally, heterotrophic bacteria may have been outcompeted for $\mathrm{P}$ and $\mathrm{N}$ by the dominant pico-autotrophic populations growing at the DCM (Engel 2004, Engel et al. 2004, Tanaka et al. 2007). The low levels of BP in the DCM and deeper waters may have enabled most of the newly formed small TEP precursors to coagulate without degrading and to aggregate to larger TEP. These larger TEP particles were then able to sink down to deeper waters as hypothesized by Beauvais et al. (2003), Burd \& Jackson (2009) and Verdugo \& Santschi (2010).

\section{Deep water column (300 to $1000 \mathrm{~m}$ )}

Although TEP were determined only at 300 and $1000 \mathrm{~m}$, we surmise that the concentrations measured at these depths were representative for the mesopelagic water column from $\sim 300$ to $1000 \mathrm{~m}$, due to the relatively uniform characteristics of this water mass during the stratified season (Krom et al. 2005). At these depths TEP and TEP-mediated aggregates (with amorphous shapes) were significantly larger than those found within the DCM (Fig. 6D). The observed increase from the DCM to $300 \mathrm{~m}$ in the concentration of larger TEP ( $>4 \mu \mathrm{m})$ (Fig. 5 ) may have been due mostly to abiotic TEP self-assembly (Verdugo et al. 2004, Verdugo \& Santschi 2010). The low rates of BP measured at these depths may have limited disintegration of these TEP as they sank to deeper waters. Low sedimentation rates of TEP and marine snow would be expected below the thermocline within the mesopelagic zone (Beauvais et al. 2003, Fischer \& Karakas 2009). Moreover, the general absence of upwelling events in the Mediterranean during this period (Krom et al. 2005, Tanaka et al. 2007, Patara et al. 2009) would tend to inhibit any upward flux of TEP (Azetsu-Scott \& Passow 2004). In general, the sedimentation of TEP and marine snow may be enhanced by the incorporation of inorganic 'ballast' material into these particles (Armstrong et al. 2001).

Most images of TEP from $1000 \mathrm{~m}$ showed relatively large $(60 \pm 33 \mu \mathrm{m})$ amorphous particles, usually with associated bacteria (Fig. 6D). BP measurements indicated that bacterial metabolism on these particles was low (Fig. 5). Nevertheless, the frequent presence of bacteria associated with significant concentrations of TEP ( 83 to $386 \mu \mathrm{g} \mathrm{GX} \mathrm{l}^{-1}$ ) in $1000 \mathrm{~m}$ samples suggests that these particles may serve as an important source of available organic carbon for slow-growing bacteria at depth.

\section{TEP as a part of the POC pool}

Expressing TEP concentrations in terms of carbon is crucial in determining the role of TEP as a constituent of the POC pool and in organic carbon cycling. Only a few studies have attempted to quantitatively evaluate the carbon content of TEP (Mari 1999, Engel \& Passow 2001). Using various cultures or natural populations of algae to generate TEP, Engel \& Passow (2001) derived a series of empirical conversion factors from micrograms of gum xanthan per liter to micrograms of carbon. We used the lowest conversion factor reported by Engel \& Passow (2001) to calculate TEP-C concentrations in relation to POC measured during the ISRALEV and SESAME cruises. This factor ostensibly yielded realistic results, indicating that TEP-C constituted from $\sim 60$ to $\sim 100 \%$ of total POC in samples from the euphotic zone. However, the same conversion factor gave unreasonably high values ( $>100 \%$ ) for TEP-C as a percentage of total POC when applied to $1000 \mathrm{~m}$ samples. As noted by Beauvais et al. (2003), TEP may be somewhat overestimated relative to POC, because the former was collected on $0.4 \mu \mathrm{m}$ polycarbonate filters, whereas the latter was collected on $\sim 0.7 \mu \mathrm{m} \mathrm{GF} / \mathrm{F}$ filters; thus, an unmeasured fraction of POC was not included. Nevertheless, it would appear that even the low conversion factor that we used is unsuitable for ultra-oligotrophic regions such as the Levantine basin, and our numerical values for TEP carbon as a percentage of total POC must be viewed with caution.

Despite the uncertainty of these absolute values, our measurements support previous reports (Azetsu-Scott \& Passow 2004, De Vicente et al. 2009), indicating that TEP-C constitutes a significant portion of the POC pool in oligotrophic seas, with an apparent tendency to increase with depth (Fig. 5). Additionally, the signifi- 


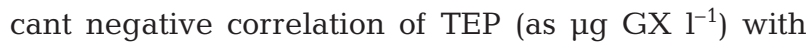
POC (as $\mu \mathrm{g} \mathrm{C}^{-1}$ ) indicated that when POC concentrations were highest, the TEP carbon contribution to the total POC pool was lowest (Fig. 8). With increasing evidence that TEP-C constitutes a non-trivial proportion of POC in many aquatic environments (De Vicente et al. 2009, Ortega-Retuerta et al. 2010), our results highlight the need for more accurate conversion factors or other direct methods of determining TEP concentrations in terms of carbon.

\section{CONCLUSIONS}

The present study provides the first description of the seasonal, spatial, and depth dynamics of TEP in the ultra-oligotrophic Levantine basin. Based on our data and published literature (Beauvais et al. 2003, Azam \& Malfatti 2007, Burd \& Jackson 2009, Patara et al. 2009, Verdugo \& Santschi 2010), we suggest the following, possible scenario for the role of TEP in organic matter cycling and flux in these waters during the stratified summer to fall season as shown schematically in Fig. 9.

In the upper euphotic zone $(0$ to $50 \mathrm{~m}$ ) relatively large $(>10 \mu \mathrm{m}) \mathrm{TEP}$, mostly released by or derived from phytoplankton, bacteria, and other plankton, provide a carbon-rich, sticky substrate for bacteria and other microorganisms and serve as a 'microbial shuttle' that transports them to deeper water. This dynamic pool of TEP is continuously formed by biotic and abiotic processes (Verdugo \& Santschi 2010), and is further modified by grazing and microbial utilization as it settles through the euphotic water column. Extracellular bacterial hydrolytic enzymes facilitate the utilization of TEP as a renewable source of available organic carbon and other nutrients that fuels the microbial pump (Verdugo et al. 2004, Azam \& Malfatti 2007). Most of this TEP is depleted before reaching the DCM, where minimal TEP concentrations and size occur. Below the DCM, TEP concentrations increase, perhaps mainly via the self-assembly aggregation pathway (Verdugo \& Santschi 2010). Sedimentation of these particles may transport significant amounts of organic matter and associated microorganisms to abyssal depths.

With depth, the proportion of the TEP-C in the pool of total POC rises and probably becomes increasingly recalcitrant (Fig. 9). In an oligotrophic region, such as the Levantine basin, the TEP fraction of the POC pool may be particularly important for carbon and nutrient cycling and distribution in an otherwise impoverished system.

Better understanding of the role of TEP in organic carbon cycling and transportation in the oceans remains a challenge. As we have shown, existing TEP carbon conversion factors are uncertain. We have no good measure of the relative amounts of TEP or TEP precursors that are formed via the aggregation pathway (Verdugo \& Santschi 2010) or are derived directly from algal or bacterial extracellular release or detrital material. Moreover, no data on the sedimentation and disintegration rates of TEP through the water column are presently available. To be able to construct more detailed oceanic carbon cycling models, quantification of these processes in terms of carbon should be the aim of future studies.

Acknowledgements. Many thanks for the hard work and help provided by Captains Daniel Schaffer and Etai Katzman and Engineer Kfir Ashkenazi of the RV 'Mediterranean Explorer', and to the EcoOcean Marine Research and Education, and to the captain and crew of the RV 'Shikmona' (Israel Oceanographic and Limnological Research). We thank Tali Yogev, Maxim Rubin, Adi Levi, and Eran Brokovitch for technical help during the cruises, and Margaret Mulholland (Old Dominion University, USA) for POC analyses. This research was supported by Israel Science Foundation grants (458/04) to I.B.-F. and 996/08 to I.B.-F. and B.H., and was partially supported by the SESAME project (036949, EUF6) to B.H. and N.K. This study is in partial fulfillment of a PhD for Edo BarZeev from Bar Ilan University.

\section{LITERATURE CITED}

Ammerman JW (1993) Microbial cycling of inorganic and organic phosphorus in the water column. In: Kemp PF, Sherr BF, Sherr EB, Cole JJ (eds) Handbook of methods in aquatic microbial ecology. Lewis, Boca Raton, FL, p 649-660

Armstrong RA, Lee C, Hedges JI, Hedges JI, Honjo S, Wakeham SG (2001) A new, mechanistic model of organic carbon fluxes in the ocean based on the quantitative association of POC with ballast minerals. Deep-Sea Res II 49: $219-236$

Azam F, Malfatti F (2007) Microbial structuring of marine ecosystems. Nat Rev Microbiol 5:782-791

Azetsu-Scott K, Passow U (2004) Ascending marine particles: significance of transparent exopolymer particles (TEP) in the upper ocean. Limnol Oceanogr 49:741-748

Bar-Zeev E, Berman-Frank I, Stambler N, Dominguez EV and others (2009) Transparent exopolymer particles (TEP) link phytoplankton and bacterial production in the Gulf of Aqaba. Aquat Microb Ecol 56:217-225

> Beauvais S, Pedrotti ML, Villa E, Lemee R (2003) Transparent exopolymer particle (TEP) dynamics in relation to trophic and hydrological conditions in the NW Mediterranean Sea. Mar Ecol Prog Ser 262:97-109

> Beauvais S, Pedrotti ML, Egge J, Iversen K, Marrase C (2006) Effects of turbulence on TEP dynamics under contrasting nutrient conditions: implications for aggregation and sedimentation processes. Mar Ecol Prog Ser 323:47-57

Berman T, Townsend DW, Elsayed SZ, Trees CC, Azov Y (1984) Optical transparency, chlorophyll and primary productivity in the eastern Mediterranean near the Israeli coast. Oceanol Acta 7:367-372

Berman-Frank I, Dubinsky Z (1999) Balanced growth in aquatic plants: Myth or reality? Phytoplankton uses the imbalance between carbon assimilation and biomass production to their strategic advantage. Bioscience 49:29-37

> Berman-Frank I, Rosenberg G, Levitan O, Haramaty L, Mari $\mathrm{X}$ (2007) Coupling between autocatalytic cell death and 
transparent exopolymeric particle production in the marine cyanobacterium Trichodesmium. Environ Microbiol 9:1415-1422

Burd AB, Jackson GA (2009) Particle Aggregation. Annu Rev Mar Sci 1:65-90

Corzo A, Morillo JA, Rodriguez S (2000) Production of transparent exopolymer particles (TEP) in cultures of Chaetoceros calcitrans under nitrogen limitation. Aquat Microb Ecol 23:63-72

De Vicente I, Ortega-Retuerta E, Romera O, Reche I (2009) Contribution of transparent exopolymer particles to carbon sinking flux in an oligotrophic reservoir. Biogeochemistry 96:13-23

> Engel A (2004) Distribution of transparent exopolymer particles (TEP) in the Northeast Atlantic Ocean and their potential significance for aggregation processes. DeepSea Res I 51:83-92

Engel A, Passow U (2001) Carbon and nitrogen content of transparent exopolymer particles (TEP) in relation to their Alcian Blue adsorption. Mar Ecol Prog Ser 219:1-10

Engel A, Thoms S, Riebesell U, Rochelle-Newall E, Zondervan I (2004) Polysaccharide aggregation as a potential sink of marine dissolved organic carbon. Nature 428:929-932

Fischer G, Karakas G (2009) Sinking rates and ballast composition of particles in the Atlantic Ocean: implications for the organic carbon fluxes to the deep ocean. Biogeosciences 6:85-102

García CM, Prieto L, Vargas M, Echevarria F, GarcíaLafuente J, Ruiz J, Rubín JP (2002) Hydrodynamics and the spatial distribution of plankton and TEP in the Gulf of Cadiz (SW Iberian Peninsula). J Plankton Res 24:817833

Grossart HP, Simon M, Logan BE (1997) Formation of macroscopic organic aggregates (lake snow) in a large lake: the significance of transparent exopolymer particles, phytoplankton, and zooplankton. Limnol Oceanogr 42:1651-1659

Harris JRW, Stutt ED, Turley CM (2001) Carbon flux in the Northwest Mediterranean estimated from microbial production. Deep-Sea Res I 48:2631-2644

Holm-Hansen O, Lorenzen CJ, Holmes RW, Strickland HJD (1965) Fluorometric determination of chlorophyll. J Cons Perm Int Explor Mer 30:3-15

Hong Y, Smith WO, White AM (1997) Studies on transparent exopolymer particles (TEP) produced in the Ross Sea (Antarctica) and by Phaeocystis antarctica (Prymnesiophyceae). J Phycol 33:368-376

Kiørboe T, Hansen J, Alldredge AL, Jackson G and others (1996) Sedimentation of phytoplankton during a spring diatom bloom: rates and mechanisms. J Mar Res 54: 1123-1148

Kirchman D, Knees E, Hodson R (1985) Leucine incorporation and its potential as a measure of protein synthesis by bacteria in natural aquatic systems. Appl Environ Microbiol 49:599-607

Kress N, Herut B (2001) Spatial and seasonal evolution of dissolved oxygen and nutrients in the Southern Levantine Basin (Eastern Mediterranean Sea): chemical characterization of the water masses and inferences on the N:P ratios. Deep-Sea Res I 48:2347-2372

Krom MD, Woodward EMS, Herut B, Kress N and others (2005) Nutrient cycling in the Southeast Levantine basin of the eastern Mediterranean: results from a phosphorus starved system. Deep-Sea Res II 52:2879-2896

Li WKW, Zohary T, Yacobi YZ, Wood AM (1993) Ultraphytoplankton in the eastern Mediterranean Sea-towards deriving phytoplankton biomass from flow cytometric measurements of abundance, fluorescence and light scat- ter. Mar Ecol Prog Ser 102:79-87

Mari X (1999) Carbon content and C:N ratio of transparent exopolymeric particles (TEP) produced by bubbling exudates of diatoms. Mar Ecol Prog Ser 183:59-71

> Ortega-Retuerta E, Reche I, Pulido-Villena E, Agusti S, Duarte CM (2009) Uncoupled distributions of transparent exopolymer particles (TEP) and dissolved carbohydrates in the Southern Ocean. Mar Chem 115:59-65

Ortega-Retuerta E, Duarte CM, Reche I (2010) Significance of bacterial activity for the distribution and dynamics of transparent exopolymer particles in the Mediterranean Sea. Microb Ecol 59:808-818

> Passow U (2000) Formation of transparent exopolymer particles, TEP, from dissolved precursor material. Mar Ecol Prog Ser 192:1-11

> Passow U (2002) Transparent exopolymer particles (TEP) in aquatic environments. Prog Oceanogr 55:287-333

Passow U, Alldredge AL (1995) A dye-binding assay for the spectrophotometric measurement of transparent exopolymer particles (TEP). Limnol Oceanogr 40:1326-1335

Patara L, Pinardi N, Corselli C, Malinverno E, Tonani M, Santoleri R, Masina S (2009) Particle fluxes in the deep eastern Mediterranean basins: the role of ocean vertical velocities. Biogeosciences 6:333-348

> Prieto L, Navarro G, Cozar A, Echevarria F, Garcia CM (2006) Distribution of TEP in the euphotic and upper mesopelagic zones of the southern Iberian coasts. Deep-Sea Res II 53: $1314-1328$

Radić T, Degobbis D, Fuks D, Radić J, Djakovac T (2005) Seasonal cycle of transparent exopolymer particles formation in the northern Adriatic during years with (2000) and without (1999) mucilage events. Fresen Environ Bull 14: $224-230$

Radić T, Ivančić I, Fuks D, Radić J (2006) Marine bacterioplankton production of polysaccharidic and proteinaceous particles under different nutrient regimes. FEMS Microbiol Ecol 58:333-342

> Simon M, Azam F (1989) Protein content and protein synthesis rates of planktonic marine bacteria. Mar Ecol Prog Ser 51:201-212

Smith DC, Azam F (1992) A simple, economical method for measuring bacterial protein synthesis rates in seawater using tritiated-leucine. Mar Microb Food Webs 6: 107-114

- Tanaka T, Zohary T, Krom MD, Law CS and others (2007) Microbial community structure and function in the Levantine Basin of the eastern Mediterranean. Deep-Sea Res I 54:1721-1743

Verdugo P, Santschi PH (2010) Polymer dynamics of DOC networks and gel formation in seawater. Deep-Sea Res II 57:1486-1493

> Verdugo P, Alldredge AL, Azam F, Kirchman DL, Passow U, Santschi PH (2004) The oceanic gel phase: a bridge in the DOM-POM continuum. Mar Chem 92:65-66

Villacorte LO, Schurer R, Kennedy MD, Amy GL, Schippers JC (2010) The fate of transparent exopolymer particles (TEP) in seawater UF-RO system: a pilot plant study in Zeeland, The Netherlands. Desal Water Treat 13: $109-119$

Wild C (2000) Effekte von marine snow-Sedimentation auf Steinkorallen (Hexacorallia, Scleractinia) des Great Barrier Reef, Australien. Dipl. Biologie/Chemie, Universität Bremen, Bremen

Zhou J, Mopper K (1998) The role of surface-active carbohydrates in the formation of transparent exopolymer particles by bubble adsorption of seawater. Limnol Oceanogr 43:1860-1871 